\title{
CHARACTERIZATION OF POLYPHENOL PROFILE OF EXTRACTS OBTAINED FROM GRAPE POMACE AND SYNERGISTIC EFFECT OF THESE EXTRACTS AND FUNGICIDES AGAINST Botrytis Cinerea
}

\author{
LEONORA MENDOZA ${ }^{a *}$, FREDDY NAVARRO $^{a}$, RICARDO MELO $^{b}$, FRANCISCO BÁEZ $^{a}$ \\ AND MILENA COTORAS ${ }^{a^{*}}$
}

${ }^{a}$ Universidad de Santiago de Chile. Facultad de Química y Biología, Alameda 3363, Estación Central, Santiago, Chile.
${ }^{b}$ Núcleo de Química y Bioquímica, Facultad de Estudios Interdisciplinario, Universidad Mayor, Santiago, Chile.

ABSTRACT

Botrytis cinerea is a phytopathogenic fungus that infects the aerial parts of approximately 250 plant species. Control of this fungus is based on synthetic fungicide application. However, it has been reported the detection of isolates of B. cinerea resistant to all fungicides. Due to the emergence of resistant isolates of phytopathogenic fungi to commercial fungicides and the concomitant reduction in the efficacy of fungicides, various strategies have been developed to prevent or delay this problem. One of them is the use of synergistic mixtures among fungicides and plant extracts. In this work, extracts obtained from grape pomace of Syrah, Cinsault, or Cabernet Sauvignon varieties were analyzed. The phenolic composition in the fractions was different. Quercetin and kaempferol were observed in all fractions, in exception of Cinsault/chloroform fraction. Interestingly, gallic acid was found only in Cinsault extracts. The flavan-3-ols catechin and (-)-epicatechin are only found in Cinsault/ethyl acetate fraction.

The effect of mixtures among these extracts and the fungicides Tercel and Cantus on mycelial growth of $B$. cinerea was analyzed. Mixtures of chloroform and ethyl acetate fractions from Cinsault grape pomace extracts and the fungicide Tercel at $0.1 \mathrm{ppm}$ showed a synergistic interaction.

Keywords: Botrytis cinerea control, grape pomace extraction, synergism.

\section{INTRODUCTION}

Botrytis cinerea, the causal agent of gray mold, is a broad pathogen that infects the aerial parts of approximately 250 plant species, affecting fruit production in pre and mainly post-harvest ${ }^{1}$.

Control of this fungus is based on synthetic fungicide application ${ }^{2}$; for this, six families of fungicides with different site-specific action mechanisms are used in the field ${ }^{3}$. However, it has been reported the detection of isolates of $B$. cinerea resistant to all fungicides families including multiresistant isolates ${ }^{2,4}$.

Due to the emergence of resistant isolates of phytopathogenic fungi to commercial fungicides, with the concomitant reduction in the efficacy of fungicides ${ }^{5}$, various strategies have been developed to prevent or delay this problem. Among them is the use of mixtures of fungicides ${ }^{5}$, mixtures of essential oils derived from plants ${ }^{6}$, or mixtures of plant extracts with fungicides ${ }^{7}$.

The use of these mixtures has allowed to decrease the fungicide doses ${ }^{8-11}$. In numerous studies, the effect of polyphenols as chemosensitizing agents of antifungal drugs in yeasts or filamentous fungi has been reported ${ }^{12}$. On the other hand, in B. cinerea it was shown that the interaction between resveratrol and pyrimethanil produces a significant synergistic effect on the mycelial growth and conidia germination ${ }^{13}$.

Phenolic compounds can be extracted from grape pomace, a low-cost-source ${ }^{14}$. Grape pomace is a waste from the wine industry whose composition varies depending on grape variety, climate, culture localization, and technology of vinification ${ }^{15}$. Grape pomace extracts, rich in anthocyanins, flavonols, and phenolic acids, have antifungal activity against the phytopathogenic fungus B.cinerea $a^{14,16,17}$. The profile of phenolic compounds in these extracts is different according to the polarity of solvent used in the extraction ${ }^{14}$.

The objective of this work was to characterize the profile of the phenolic compounds of grape pomace extracts obtained from Syrah, Cinsault, or Cabernet Sauvignon varieties and the possible synergistic effect of mixtures among these extracts and fungicides on mycelial growth of $B$. cinerea. The effect of extracts and mixtures on cell wall and cell membrane integrity of $B$. cinerea was also evaluated.

\section{EXPERIMENTAL}

\section{Grape pomaces}

Pomaces were obtained after grape fermentation from $V$. vinifera varieties (Syrah, Cinsault, and Cabernet Sauvignon) of the 2017 harvest season in Santa Rita Vineyard (Buin, Chile). Pomaces were maintained at $-20^{\circ} \mathrm{C}$ until they were used.

\section{Extraction process}

Extracts were prepared from dry ground grape pomace (60 $\mathrm{g}$ of wet ground pomace were dried at $50^{\circ} \mathrm{C}$ ), and the phenolic compounds were extracted with methanol/ $/ \mathrm{HCl}(1 \% \mathrm{v} / \mathrm{v})$ for $4 \mathrm{~h}$ with constant agitation at $40{ }^{\circ} \mathrm{C}$. Extracts were concentrated in a rotary evaporator, and distilled water $(10 \mathrm{~mL})$ was added. Then, the volume was decreased in a rotary evaporator. Water addition was repeated three times. Finally, aqueous suspension or crude extract was subjected to sequential liquid-liquid extraction with hexane, chloroform and finally ethyl acetate. All extractions were made at least in triplicate. Yields were calculated based on dry vegetal.

\section{Determination of total phenol content}

The amount of total phenols of all extracts was determined by a modified Folin-Ciocalteu's reagent method described by Zhang et al. $(2006)^{18}$. The FolinCiocalteu's reagent used in these experiments was obtained from Merck (Santiago, Chile), and the absorbance was measured at $750 \mathrm{~nm}$ on a MultiSkan GO microplate spectrophotometer (Thermo Scientific, Waltham, MA, USA). Total phenols content was expressed as gallic acid equivalent (milligrams of gallic acid per gram of extracted compounds).

\section{Analysis of phenolic compounds in different extracts}

The phenolic compound analysis was done by high-performance liquid chromatography as described by Mendoza et al. (2013) $)^{14}$. A Waters 600 HPLC chromatograph (Waters, Milford, MA, USA) equipped with a Waters 2990 diode array detector and a Symmetry C-18 $(5 \mu \mathrm{m}, 3.9 \mathrm{~mm} \times 150 \mathrm{~mm})$ column (Waters) was used.

Identification of phenolic compounds was made by comparing their retention times and UV-Vis spectra with the following standards (Merck, Santiago, Chile): gallic acid, protocatechuic acid, vanillic acid, sinapic acid, syringic acid, ellagic acid, (+)-catechin, (-)-epicatechin, epigallocatechin, caffeic acid, vanillin, $\mathrm{p}$ coumaric acid, 4-hydroxy-3,5-dimethoxybenzaldehyde, 4-hydroxyphenylacetic acid, trans-resveratrol, quercetin, kaempferol and myricetin.

\section{Fungal isolate and culture conditions}

In this study, isolate G29 of $B$. cinerea was used. This strain was originally isolated from naturally infected grapes $(V \text {. vinifera })^{19}$ and was maintained on malt-yeast extract agar slants (2\% (w/v) malt extract, $0.2 \%(\mathrm{w} / \mathrm{v})$ yeast extract and $1.5 \%(\mathrm{w} / \mathrm{v})$ agar) at $4{ }^{\circ} \mathrm{C}$. The fungus was grown in the dark on potato dextrose agar or soft agar medium $(2.4 \%(\mathrm{w} / \mathrm{v})$ potato dextrose broth and $0.6 \%$ (w/v) agar). 


\section{Synergistic effect determination}

A preliminary screening of all mixtures between fungicide and extracts was realized in 24-well plates to select some of them for further experiments. These mixtures were created from fungicides at $0.05 \mathrm{ppm}$ and $0.1 \mathrm{ppm}$, and from all extracts, $\mathrm{t}$ at 40 and $160 \mathrm{ppm}$ from hexane, chloroform or ethyl acetate fractions of three grape pomaces.

To carry out the synergy analyses, the effect of extracts, commercial fungicides Cantus $^{\mathrm{TM}} 50$ WG (50\% boscalid, BASF SE, Germany) or Tercel ${ }^{\mathrm{TM}} 50 \mathrm{WP}$ (iprodione 50\%, ANASAC, Chile) and mixtures of extracts and fungicide on mycelial growth was determined in vitro using the radial growth test described by Mendoza et al. $(2009)^{20}$. Extracts or fungicides were dissolved in acetone at different final concentrations. Mycelial growth was measured after $96 \mathrm{~h}$ of incubation at $22^{\circ} \mathrm{C}$. All the experiments were performed at least in triplicate and with adequate controls (solvent and positive control).

To determine a synergistic effect, the Abbott formula ${ }^{21}$ described in equation 1 was used.

$$
E_{\exp }=a+b-(a b)
$$

In which $\mathrm{E}_{\text {exp }}$ is the expected control efficacy of a mixture, $a$ and $b$ represent the proportion of the population controlled by fungicides or extracts.

$$
\mathrm{SF}=\mathrm{E}_{\mathrm{obs}} / \mathrm{E}_{\exp }
$$

SF is the synergy factor, corresponding to the ratio between the observed experimental efficacy of the mixture and the expected efficacy. If this ratio is smaller than one, indicates an antagonist interaction, if SF is greater than one is a synergistic interaction and finally if the ratio is close to one is an additive interaction.

All the experiments were performed at least in triplicate and with adequate controls (solvent and positive controls)

Effect of extracts and mixtures on cell wall and cell membrane integrity of $B$. cinerea

The effect on cell wall integrity of $B$. cinerea was determined using fluorochrome Calcofluor White (Sigma-Aldrich, USA) and the effect on plasmatic membrane integrity of B. cinerea was determined using the SYTOX Green uptake assay (Molecular Probes, Eugene, OR, USA) ${ }^{22}$, as Morales et al. (2017) described ${ }^{23}$. In both assays, $B$. cinerea conidia at a final concentration of $1 \times 10^{5}$ conidia /mL were inoculated in 24 -well plates containing culture media. The conidial suspension was incubated at $22^{\circ} \mathrm{C}$ for $15 \mathrm{~h}$. After this, the germinating conidia were resuspended in the same medium in the presence of extracts, fungicide or mixtures. In cell wall integrity assays, $1 \mathrm{mg} / \mathrm{L}$ of Lysing Enzymes from Trichoderma harzianum (Sigma-Aldrich, USA) was used as positive control. In cell membrane integrity assays, $70 \%$ ethanol was used as positive control. In both assays, acetone at the same concentration as treatments was used as negative control.

The fluorescence of $B$. cinerea hyphae stained with the fluorochromes was observed under a confocal microscope (Carl Zeiss LSM 510) at an excitation wavelength of $488 \mathrm{~nm}$ and an emission wavelength of $540 \mathrm{~nm}$ for SYTOX Green, and at an excitation wavelength of $355 \mathrm{~nm}$ and an emission wavelength of 433 $\mathrm{nm}$ for Calcofluor White. These experiments were done at least in triplicate.

\section{Statistical analysis}

Statistical analyses were carried out using the software IBM SPSS Statistics v. 25 and treatment means were compared using one-way ANOVA and Tukey tests at $p<0.05$. All experiments for antifungal activity and synergism determination were made at least in triplicate. The Grubbs test was performed to find outliers in all experiments.

\section{RESULTS}

\section{Extraction yields}

The extraction yield from three grape pomaces was similar to previous work with different grape pomaces and extraction methods ${ }^{14}$, among 0.3 and $1.2 \%$ (Table 1). Hexane fractions from Syrah and Cinsault presented the highest extraction yields. The lower extraction yields were obtained in the chloroform fractions of the three grape pomace varieties.
Finally, all ethyl acetate fractions had higher yield regarding previous work ${ }^{14}$. In that work, a mixture of grape pomaces and a low extraction temperature was used ${ }^{14}$.

Table 1. Extraction yield of three grape pomaces

\begin{tabular}{|l|l|c|}
\hline Grape pomace variety & Extract fraction & Yield (\%) \\
\hline \multirow{4}{*}{ Syrah } & Hexane & 1.2 \\
\cline { 2 - 3 } & Chloroform & 0.5 \\
\cline { 2 - 3 } & Ethyl acetate & 0.8 \\
\hline \multirow{4}{*}{ Cinsault } & Hexane & 0.8 \\
\cline { 2 - 3 } & Chloroform & 0.3 \\
\cline { 2 - 3 } & Ethyl acetate & 0.8 \\
\hline \multirow{3}{*}{ Cabernet Sauvignon } & Hexane & 0.3 \\
\cline { 2 - 3 } & Chloroform & 0.6 \\
\cline { 2 - 3 } & Ethyl acetate & 1.0 \\
\hline
\end{tabular}

\section{Phenolic profile from grape pomaces}

The quantity of total phenols expressed as gallic acid equivalents is summarized in Table 2. Quantity of total phenols varied depending on the polarity of solvents used. With the more polar solvent, the highest quantity of total phenols in three grape varieties was obtained. There were not significant differences in the total phenols in the hexane and chloroform fractions, in exception of hexane fraction of Cabernet Sauvignon in which fewer amount of total phenols was obtained. The fraction of ethyl acetate from Cabernet Sauvignon grape pomace had the highest content of total phenols. The effect of solvent polarity in the extraction of phenols reported in this work was similar to previous report in which grape pomace extracts from similar grape varieties but obtained from different harvest season and vineyard were used ${ }^{24}$. The only difference was that they reported differences in total phenols among hexane and chloroform fractions ${ }^{14}$.

Table 2. Pomace grape varieties and its total phenolic compounds expressed

\begin{tabular}{|c|c|c|c|}
\hline $\begin{array}{l}\text { Grape pomace } \\
\text { variety }\end{array}$ & $\begin{array}{l}\text { Extract } \\
\text { fraction }\end{array}$ & $\begin{array}{c}\text { Gallic acid } \\
\text { equivalent }(\mathrm{mg} / \mathrm{g})\end{array}$ & $\begin{array}{l}\text { Phenolic } \\
\text { compounds }\end{array}$ \\
\hline \multirow{3}{*}{ Syrah } & Hexane & $16.6 \pm 4.1^{b}$ & n.d. \\
\hline & Chloroform & $16.9 \pm 4.1^{\mathrm{b}}$ & n.d. \\
\hline & Ethyl acetate & $77.2 \pm 23.4^{\mathrm{c}}$ & n.d. \\
\hline \multirow{3}{*}{ Cinsault } & Hexane & $13.4 \pm 3.7^{b}$ & $\begin{array}{c}\text { Gallic acid } \\
\text { Ellagic acid } \\
\text { Quercetin } \\
\text { Kaempferol }\end{array}$ \\
\hline & Chloroform & $11.3 \pm 4.5^{\mathrm{b}}$ & Gallic acid \\
\hline & Ethyl acetate & $85.5 \pm 10.1^{\mathrm{c}}$ & $\begin{array}{c}\text { Gallic acid } \\
\text { Catechin } \\
\text { (-)-epicatechin } \\
\text { Quercetin } \\
\text { Kaempferol }\end{array}$ \\
\hline \multirow{3}{*}{$\begin{array}{l}\text { Cabernet } \\
\text { Sauvignon }\end{array}$} & Hexane & $5.1 \pm 1.4^{\mathrm{a}}$ & $\begin{array}{c}\text { Quercetin } \\
\text { Kaempferol } \\
\end{array}$ \\
\hline & Chloroform & $19.4 \pm 7.2^{b}$ & $\begin{array}{c}\text { Quercetin } \\
\text { Kaempferol } \\
\text { Phenolic acid } \\
\text { traces }\end{array}$ \\
\hline & Ethyl acetate & $142.1 \pm 11.9^{\mathrm{d}}$ & $\begin{array}{c}\text { Quercetin } \\
\text { Kaempferol } \\
\text { Flavonoid } \\
\text { traces }\end{array}$ \\
\hline
\end{tabular}
as gallic acid equivalent and its chemical composition.

n.d. not determined. Each value corresponds to the mean of three independent experiments \pm standard deviation. Different letters correspond to a significant difference. $P<0.05$.

The phenolic composition in the different fractions was different. Quercetin and kaempferol were observed in all fractions, excepting in Cinsault/chloroform fraction. Mendoza et al. (2013) $)^{14}$ observed that both molecules are found in all 
fractions from pomaces analyzed when they used methanol in the extraction process ${ }^{14}$. Interestingly gallic acid was found only in Cinsault extracts. The flavan-3-ols catechin and (-)-epicatechin were only found in Cinsault/ethyl acetate fraction.

\section{Antifungal activity and synergism analysis}

To determine possible synergistic interactions among the fungicides Tercel and Cantus and the different fractions from grape pomace, 72 preliminary mixtures were analyzed in 24-well plates. For this, two concentrations of each fungicide and two concentrations for each fraction were used. None fraction from grape pomaces had antifungal effect on $B$. cinerea (Results not shown).

From this screening, nine mixtures with a synergistic behavior were selected. None of the selected mixtures had fractions of Syrah extracts, seven mixtures corresponded to fractions of Cinsault extract (Table 3, mixtures A-G), and two to Cabernet Sauvignon (Table 3, mixtures I and J). Also, three mixtures without synergistic interaction (Table 3, mixtures $\mathrm{H}, \mathrm{K}$, and $\mathrm{L}$ ) were selected. All mixtures selected corresponded to chloroform or ethyl acetate fractions, and most of them contained Tercel. The composition of the selected mixtures is shown in Table 3.

Table 3. Mixtures between grape pomace extracts and fungicides.

\begin{tabular}{|c|l|}
\hline Mixture & Composition \\
\hline A & Cinsault / Chloroform $40 \mathrm{ppm}+$ Tercel $0.05 \mathrm{ppm}$ \\
\hline B & Cinsault / Chloroform $40 \mathrm{ppm}+$ Tercel $0.1 \mathrm{ppm}$ \\
\hline $\mathrm{C}$ & Cinsault / Chloroform $160 \mathrm{ppm}+$ Tercel $0.05 \mathrm{ppm}$ \\
\hline $\mathrm{D}$ & Cinsault / Ethyl acetate $40 \mathrm{ppm}+$ Tercel $0.05 \mathrm{ppm}$ \\
\hline $\mathrm{E}$ & Cinsault / Ethyl acetate $40 \mathrm{ppm}+$ Tercel $0.1 \mathrm{ppm}$ \\
\hline $\mathrm{F}$ & Cinsault / Ethyl acetate $160 \mathrm{ppm}+$ Tercel $0.05 \mathrm{ppm}$ \\
\hline $\mathrm{G}$ & Cinsault / Ethyl acetate $160 \mathrm{ppm}+$ Tercel $0.1 \mathrm{ppm}$ \\
\hline $\mathrm{H}$ & Cinsault / Ethyl acetate $160 \mathrm{ppm}+$ Cantus $0.1 \mathrm{ppm}$ \\
\hline $\mathrm{I}$ & Cabernet Sauvignon / Chloroform $160 \mathrm{ppm}+$ Tercel $0.1 \mathrm{ppm}$ \\
\hline $\mathrm{J}$ & Cabernet Sauvignon / Chloroform $160 \mathrm{ppm}+$ Cantus $0.1 \mathrm{ppm}$ \\
\hline $\mathrm{K}$ & Cabernet Sauvignon / Ethyl acetate $160 \mathrm{ppm}+$ Tercel $0.1 \mathrm{ppm}$ \\
\hline $\mathrm{L}$ & Cabernet Sauvignon / Ethyl acetate $160 \mathrm{ppm}+$ Cantus $0.1 \mathrm{ppm}$ \\
\hline
\end{tabular}

The effect of these mixtures on mycelial growth of $B$. cinerea represented as the synergy factor, corresponding to the ratio between the observed experimental inhibition of the mixture and the expected inhibition, is shown the Figure 1. If this ratio is lower than one indicates an antagonist interaction. It can be concluded that the mixtures $\mathrm{H}$, I and L showed an antagonistic interaction. Mixture $\mathrm{K}$ also presented antagonistic interaction (Result not shown). If the ratio between observed experimental inhibition of the mixture and the expected inhibition is greater than one indicates a synergistic interaction. It can be concluded that the mixtures $\mathrm{B}, \mathrm{E}$, and $\mathrm{G}$, all mixtures with Cinsault grape pomace extracts and Tercel at $0.1 \mathrm{ppm}$, showed a synergistic interaction. The remaining mixtures showed an additive interaction, considering that the ratio is close to one.

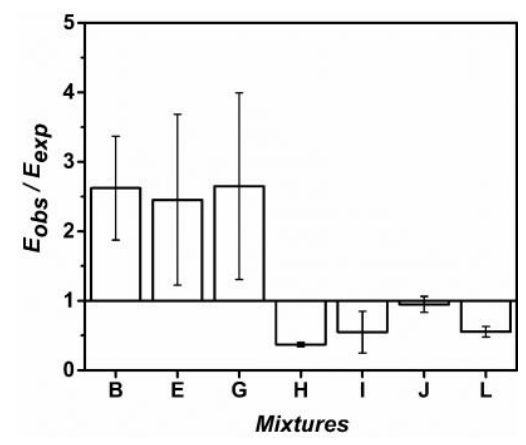

Figure 1. Effect of the mixtures on mycelial growth of $\mathrm{B}$. cinerea. In this figure, the ratio among the observed inhibition and the expected inhibition is shown. Each bar corresponds to mean of three independent experiments \pm standard deviation.

\section{Evaluation of the mode of action of extracts and mixtures on $\boldsymbol{B}$. cinerea}

To evaluate the mode of action of the extracts or mixtures, the effect on the cell wall and cell membrane integrity of $B$. cinerea was evaluated using Calcoflour White or Sytox Green, respectively. None of extracts or mixture affected the integrity of the cell wall or cell membrane (results not shown). Therefore, the extracts or fungicides did not act on these structures.

\section{CONCLUSIONS}

Different extracts were prepared from grape pomace obtained from Syrah, Cinsault, and Cabernet Sauvignon varieties. The phenolic composition in the fractions was different. Quercetin and kaempferol were observed in all fractions, excepting in Cinsault/chloroform fraction. Interesting, gallic acid was found only in Cinsault extracts. The flavan-3-ols catechin and (-)-epicatechin are only found in Cinsault/ethyl acetate fraction. All mixtures with Cinsault grape pomace extracts and the fungicide Tercel at $0.1 \mathrm{ppm}$ showed a synergistic effect on B. cinerea.

\section{ACKNOWLEDGMENTS}

The authors thank DICYT-Usach 021742ME for their financial support and Daniel Valdes from Laboratorio de Microscopía Confocal de la Universidad de Santiago de Chile for his useful help. Also the authors thank to Freddy Navarro Doctoral fellowship (Conicyt 21150868).

\section{REFERENCES}

1. Y. Elad, B. Williamson, P. Tudzynski, N. Delen. in Botrytis Biol. Pathol. Control, edited by Y. Elad, B. Williamson, P. Tudzynski, and N. Delen (Springer Netherlands, Dordrecht, 2007), pp. 1-8.

2. M. Hahn. J. Chem. Biol. 7, 133, (2014).

3. M. Esterio, G. Muñoz, C. Ramos, G. Cofré, R. Estévez, A. Salinas, J. Auger. Plant Dis. 95, 683, (2011).

4. B.A. Latorre, R. Torres. Crop Prot. 40, 49, (2012).

5. F. van den Bosch, N. Paveley, M. Shaw, P. Hobbelen, R. Oliver. Plant Pathol. 60, 597, (2011).

6. F. Hossain, P. Follett, K. Dang Vu, M. Harich, S. Salmieri, M. Lacroix. Food Microbiol. 53, 24, (2016).

7. B. Fielding, C.-L. Knowles, F. Vries, J. Klaasen. Agriculture 5, 400, (2015).

8. J.H. Kim, B.C. Campbell, N. Mahoney, K.L. Chan, R.J. Molyneux, G.S. May. Lett. Appl. Microbiol. 45, 134, (2007).

9. J.H. Kim, B.C. Campbell, N. Mahoney, K.L. Chan, R.J. Molyneux, G.S May. FEMS Microbiol. Lett. 270, 284, (2007).

10. J.H. Kim, B.C. Campbell, N. Mahoney, K.L. Chan, R.J. Molyneux. Mycopathologia 171, 291, (2011).

11. V. Dzhavakhiya, L. Shcherbakova, Y. Semina, N. Zhemchuzhina, B. Campbell. Front. Microbiol. 3, 1, (2012).

12. S.A. Zacchino, E. Butassi, M. Di Liberto, M. Raimondi, A. Postigo, M. Sortino. Phytomedicine 37, 27, (2017).

13. D. Xu, G. Yu, P. Xi, X. Kong, Q. Wang, L. Gao, Z. Jiang. Molecules 23, $1455,(2018)$

14. L. Mendoza, K. Yañez, M. Vivanco, R. Melo, M. Cotoras. Ind. Crops Prod. 43, 360, (2013).

15. A. Schieber, F.. Stintzing, R. Carle. Trends Food Sci. Technol. 12, 401, (2001).

16. L. Mendoza, M. Cotoras, M. Vivanco, B. Matsuhiro, S. Torres, M.J. Aguirre. J. Chil. Chem. Soc. 58, 1725, (2013).

17. M. Cotoras, H. Vivanco, R. Melo, M.J. Aguirre, E. Silva, L. Mendoza. Molecules 19, 21154, (2014).

18. Q. Zhang, J. Zhang, J. Shen, A. Silva, D.A. Dennis, C.J. Barrow. J. Appl. Phycol. 18, 445, (2006).

19. G. Muñoz, P. Hinrichsen, Y. Brygoo, T. Giraud. Mycol. Res. 106, 594, (2002).

20. L. Mendoza, P. Espinoza, A. Urzúa, M. Vivanco, M. Cotoras. Molecules 14, 1966, (2009).

21. Y. Levy, M. Benderly, Y. Cohen, U. Gisi, D. Bassand. EPPO Bull. 16, 651, (1986).

22. K. Thevissen, F.R. Terras, W.F. Broekaert. Appl. Environ. Microbiol. 65, 5451, (1999).

23. J. Morales, L. Mendoza, M. Cotoras. J. Appl. Microbiol. 123, 969, (2017).

24. L. Sanhueza, M. Tello, M. Vivanco, L. Mendoza, M. Wilkens. Adv. Microbiol. 04, 225, (2014). 